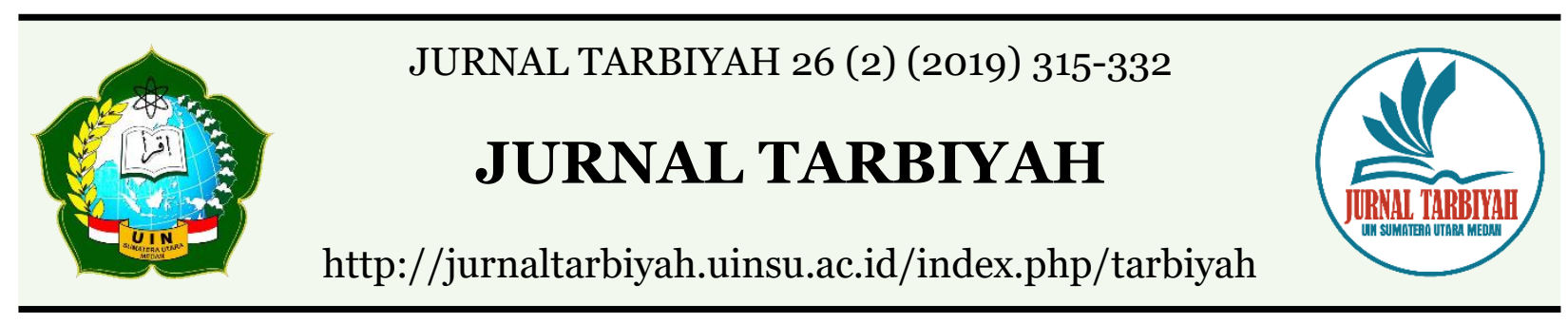

\title{
THE RELATIONSHIP OF ONLINE GAMES ADDICTION WITH TEACHING SOCIAL SKILLS IN THE COMMUNICATION SCIENCE STUDENTS OF STATE ISLAMIC UNIVERSITY OF NORTH SUMATERA
}

\author{
Elda Ayumi' ${ }^{1}$, Iskandar Zulkarnain², Yan Hendra3 ${ }^{3}$ \\ 1,2,3Universitas Muhammadiyah Sumatera Utara (UMSU), Medan, Indonesia \\ Email : eldaayumig6@gmail.com
}

DOI : 10.30829/tar.v26i2.519

Accepted: September 17th, 2019. Approved: December 19th, 2019. Published: December 25th, 2019

\begin{abstract}
This research was conducted among communication science students of State Islamic University Medan of North Sumatra, the aim of this study is to determine the level of social skills in adolescents, online game addiction level, and the relationship of online game addiction with social skills in adolescents among communication science students of State Islamic University of North Sumatra. This research uses quantitative methods. Research subjects were 186 respondents who were selected using random sampling. In collecting data, researchers used a Likert scale. The analysis of data in this study uses simple linear regression. In this study, researchers used the Sociopsycholog theory from Little Jhon. The results of the research conducted, it is known that (1) the level of online game addiction in adolescents among communication science students at the State Islamic University of North Sumatra is in the medium category with a percentage of $69.4 \%$. (2) while the level of social skills of adolescents among communication students of State Islamic University of North Sumatra Medan is in the medium category with a percentage of $85.5 \%$ or 159 subjects (3) known also (correlation coefficient 0.215 with p $=0.000$ and Sig scores .2-tailed 0.05) which means that there is a significant relationship between online gaming addiction and social skills among students of communication science at the State Islamic University of North Sumatra in Medan.
\end{abstract}

Keywords: Online Game Addiction, Youth Social Skills, Students. 
Elda Ayumi, Iskandar Zulkarnain, Yan Hendra / JURNAL TARBIYAH 26 (2) (2019) 315-332

\section{INTRODUCTION}

Communication is done without having to face to face directly can occur due to the emergence of the internet. The internet is not owned, controlled or managed by a single body but is an intentionally connected computer network that operates according to a mutually agreed protocol. A number of organizations, especially telecommunications providers and agencies play a role in internet operations (McQuail, 2011: 28-29). With the advent of the internet, every human being can communicate without having to meet physically or face to face.

The presence of the internet allows humans to communicate without knowing the limits of space and time. A person, wherever he is, as far as whatever he is, during using the internet, he can communicate quickly and easily without having to meet in person (face to face). These inherited patterns of life tend to gradually shift or even begin to disappear altogether because they are replaced by new life patterns, especially those that occur in urban areas. As an example of the pattern of children's games today, children today tend to begin to leave the traditional form of play and move to more modern games, this can be identified by looking at the loneliness of the field, starting to lose the traditional game competition and starting to crowded places which provides more modern forms of games, such as Internet Cafes.

In a survey conducted by the US Federal Networking Council, within a period of 20 years, since the first use of the internet was opened to the public, now internet users in the world reach more than 1.4 billion, or about $21 \%$ of the total world population. In Asia, the first country with the highest number of internet users is China with a total of 253 million users or about $19 \%$ of the total population of China. Whereas in Indonesia, the Association of Indonesian Internet Service Providers (APJII) recently conducted a survey of internet users in Indonesia. The result is the number of active internet users in Indonesia has reached 63 million people, or about $24 \%$ of the total population of Indonesia. This number has increased by $8 \%$ compared to last year, where currently there are only around 55 million users.

Most Internet users are still in Java. The second position was followed by the islands of Sumatra, Sulawesi, Bali and Kalimantan. While in the Province, the most users are in West Java. Then followed by East Java and Central Java. Judging from the clarification of age, most Internet users are still aged 12-34 years, which reaches 64 percent of total users. Of course this is not a positive result for adolescents in Indonesia, in previous studies internet addiction can cause adolescents to experience social life that 
is isolated and tend to shut down, this causes adolescents to begin to have no control over their social life, one example is the decline in social skills.

One that is offered by the internet itself to children is of course online game play. According to Kin et al (2002: 24) Online Games are games (games) where many people can play at the same time through online communication networks (LAN or the Internet). Various games are created and then played by those who download. In fact, most players do not know each other in the real world, only limited in the online world. Online games with all kinds of charms make players feel at home for long in front of the computer. Online games that are so exciting make the game players forget time, forget themselves and forget other things in the environment. Games are fun and entertaining games for children as one of its users. Children are invited to explore another world full of challenges and increase their adrenaline. Many things they can learn. In addition, they can also become superior (heroes) by holding control over the characters in it. In order to be able to walk in accordance with the wishes of the players, which is to be a winner with minimum points to reach a certain target. This certainly makes children experience addiction to online games.

Grispon \& Bokular (Elster, 1999: 3) stated that addiction or addiction is a state of interaction between psychic and sometimes physical of living organisms and drugs, distinguished by behavioral responses and other responses that always include a necessity to take drugs continuously or periodically for experiencing psychological effects, and sometimes to avoid the discomfort of the absence of drugs. When someone does not get more of a substance or act, they become very restless, easily offended, and feel displeased. Someone is said to be addicted to online games if the preferred activity dominates at the level of thought and behavior. Then people who are addicted to online games will feel the effects of pleasure when playing online games (Euphoria).

At the age of 12-34 years the age of the most experienced addiction to online games where adolescents in the age range 12-23 years are the biggest players, at that time teens are in the period of looking for identity. Adolescence itself is a part of the process of continuous growth and development, which is a transition from childhood to early adulthood. At this stage there is rapid growth and development in physical, emotional, cognitive and social aspects. Adolescence (adolescene) is defined as a period of developmental transition between childhood and adulthood which includes biological, cognitive, and social-emotional changes (Santrock, 2003: 92). 
The age limit for teens commonly used by experts is between 12 years and 21 years. The time span of adolescence is usually divided into three, namely 12-15 years as early adolescence, 15-18 years as middle adolescence, 18-21 years as late adolescence. But Monks, Knoers, and Haditono differentiate adolescence into four, namely preadolescence 10-12 years, early adolescence 12-15 years, adolescence mid-15-18 years, and adolescence late 18-21 years (Deswita, 2006: 133).

Psychological changes in adolescents usually appear in the presence of explosive emotions, difficult to control, quickly depressed (sad, hopeless) and then fight and rebel. These uncontrolled emotions are caused by role conflicts that teenagers like to experience. Therefore, psychological development is emphasized in the emotional state of adolescents. The emotional state in adolescence is still unstable because it is closely related to the state of hormones in the body. Adolescence is a transition period, when individuals try to achieve independence so that they can be accepted and recognized as adults. Teenagers also began to think critically and extend relationships. The success of adolescents through this period is influenced by both individual factors (biological, cognitive, and psychological) and the environment (family, peers, and society).

The dependence of internet online games experienced in adolescence, can affect the social aspects of adolescents in living their daily lives (Orleans \& Laney, 1997: 64). Because the amount of time spent in cyberspace results in teens not interacting with others in the real world. This certainly affects the social skills possessed by a teenager. According to Putallaz \& Gottman (in Dodge, Pettit, McClaskey, Brown, \& Gottman, 1986: 73) social skills are aspects of social behavior that are important to consider in order to prevent physical or pathological illness in children and adults. In adolescents social skills are needed in social communication. Social skills also have an influence on the future of one's life.

At present, the Mobile Legends application has been downloaded 35 million times and there are 8 million active daily users in Indonesia. The number of active players is targeted to continue to grow along with innovations and new features released by Moonton in Indonesia. This game has successfully become a phenomenon among children, adolescents, and students. Cellular legend can cause a very severe addiction for its users because this game presents excitement and deep curiosity for the younger generation.

Students can sit for hours and play with this game. The game addicts even forget about the environment that should be invited to communicate instead ignored because of 
the presence of this game. Even now there are many students who play online Mobile Legend games in hangouts such as cafes. Many students also play this game on campus and between their free time while waiting for the lecturer or friend. This game is not only played by men, but women (female students) are also not uncommon to play the game Mobile Legend and PUBGM. In addition to the convenience offered because this game is used on smart phones, this game seems to be addictive for people who play it. In addition to mobile legend, some games that also target students include PUBGM, ML, AOV, FreeFire, and so on.

Students have a greater risk related to internet problems, especially excessive internet use. Seventy-two percent of students are internet users, and $87 \%$ of students have access to the internet. One factor of excessive internet use is related to development problems. Although students are considered as adults, this allows students to work together or build relationships with others, but for some students who have poor social relations, they will experience difficulties in establishing relationships or relationships in real life. In the virtual world, they will feel more open, not feel shy, smarter, and even have good social skills.

Researchers decided to conduct research at the North Sumatra State Islamic University in Medan, because in addition to researchers being alumni of the campus, so researchers would be more familiar with the character of the location and also the object of research. In addition, because based on observations made in the field, most students majoring in communication at the North Sumatra State Islamic University in Medan have an interest in online games that are developing today such as PUBGM, ML, AOV, FreeFire, Hago, Get-Rich Line and so on.

\section{LITERATURE REVIEW}

\section{Communication}

Etymologically according to its origin the term communication in English comes from the Latin word communis which means "same", or communico, communication and communicare which means "to make common" (to make common). The first term (communis) is most often referred to as the origin of the word communication, which is the root of other similar Latin words. Communication suggests that a thought, a meaning, or a message is held in common. However, contemporary definitions suggest that communication refers to the way of sharing these things, as in the phrase "we share thoughts", "we discuss meaning", and "we send messages" (Mulyana, 2010: 46). 
In addition Effendy said communication as a communication process is essentially the process of delivering thoughts, or feelings by someone (communicator) to others (communicant). The mind can be ideas, information, opinions and others that arise from his mind. Feelings can be in the form of beliefs, certainty, doubts, worries, anger, courage, excitement, and so forth arising from the bottom of the heart (Effendy, 2013: 11). The function of communication in general is that communication is not only a process of delivering and receiving information, but also has a role and function as a process of building relationships between communication actors.

Thus, the essence of communication is news. Communication is also used to develop relationships between friends and build trust between individuals and one's friendship in an organization (Nurjaman, 2012: 44-45). The purpose of communication is to expect understanding, support, ideas and actions. Every time we intend to establish communication then we need to examine what our goals are, do we want to explain something to others or do we want others to do something.

It is not easy to communicate effectively. Even some communication experts state that it is impossible for someone to do a truly effective communication. There are many obstacles that can damage communication. There are a number of things that are communication barriers that must be a concern for communicators if they want to communicate successfully. This in the world of communication is called noise (communication disturbance). The communication process will not run smoothly if there is a disruption in communication. Disturbances or obstacles in general can be grouped into internal barriers and external barriers.

\section{Socio-Psychology Communication Theory}

Sociopsychological tradition covers the scope of attention between individual behavior, personality, influence and individual nature of doing a perception. In this theory individual studies are linked to social beings which is a goal of this sociopsychological tradition. Social psychology is based on a tradition that has other strong traditions in communication. Sociopsychological traditions are widely used in the study of individual self, conversation, message, interpersonal relationships, groups, media, organizations, culture and even society. Although this theory has a lot of differences, but pay attention to a behavior and personal nature and also a cognitive process that leads to a behavior. 
Elda Ayumi, Iskandar Zulkarnain, Yan Hendra / JURNAL TARBIYAH 26 (2) (2019) 315-332

The main effect measured is the change or difference of opinion expressed by the attitude given and the message delivered by the communicator to the communicant. Theories from psychosocial can also explain about the processes that are taking place in humans when communicating. Humans when the communication process takes place produce messages and involve processes internally and externally that exist within humans themselves such as for example thinking, making decisions, and also the process of using symbols. Therefore the process of understanding the message that has been received, humans also use psychological processes to think, understand and use memories so that the formation of meaning.

\section{Online Game Addiction}

The word addiction is usually used in a clinical context and refined with excessive behavior. The concept of addiction can be broadly applied to behavior including information communication technology (ICT) addiction. Addiction to online games is one type of addiction caused by internet technology or better known as internet addictive disorder. As mentioned by Young (2000: 475) which states that the internet can cause addiction, one of which is Computer game Addiction (excessive playing games). From this it can be seen that online games are part of the internet that is frequently visited and very popular and can even result in addictions that have a very high intensity.

Based on the above explanation, addiction is a dependent behavior or a bound condition that is very strong physically and psychologically in doing something, and there is an unpleasant feeling if it is not fulfilled. So the notion of online gaming addiction is a condition of someone who is bound to very strong habits and can not be separated to play online games, from time to time there will be an increase in the frequency, duration or amount of doing so, regardless of the negative consequences that exist on himself.

Adolescents who are addicted to online game play are included in the three criteria set by WHO (World Health Organization), which are in dire need of games with symptoms of withdrawing from the environment, losing a ride, and not caring about other activities. Aspects of someone addicted to online games include someone who will experience Compulsion (compulsive / encouragement to do continuously), Withdrawal (withdrawal), Tolerance (tolerance), Interpersonal and health-related problems (problems of interpersonal relationships and health).

Online games have many types, ranging from simple text-based games to games that use complex graphics and form a virtual world that is occupied by many players at 
once. So the factors causing teenagers addicted to online games are Relationship (the desire to interact with others), Manipulation (the desire to make other players as objects and their manipulation for satisfaction and wealth), Immersion (players who really like to be other people), Escapism (playing online games to avoid and forget problems in real life), and Achievement (desire to be strong in a virtual world environment.

The effects arising from playing online games are twofold, namely positive and negative impacts. The positive impact of playing this online game, among others, can master the computer, can understand English, from this online game can add friends, and for those who already have an ID from one of the online games can sell it to others and finally get money from the results. . While the negative impacts of playing online games include wasting time and money in vain, making people addicted, sometimes more willing to give up college to play online games (skipping college), can make forget time, to eat, worship, time to go home, with too often dealing with computer monitors or cellphone screens in the naked eye can make a minus eye, a child often lies to his parents because at first say goodbye to go to school / college it turns out he skipped to play online games.

\section{Social Skill}

Social skills are specific behaviors, initiatives, aiming at expected social outcomes as a form of behavior for someone (Merrell, 1998: 40). Furthermore, according to Hargie, Saunders, \& Dickson, social skills are the ability of individuals to communicate effectively with others both verbally and nonverbally according to the situation and conditions at the time, and can establish good relationships (socializing) with others, where this skill is the behavior learned. Teenagers with social skills will be able to express both positive and negative feelings in interpersonal relationships, without having to hurt others or lose social recognition (in Gimpel \& Merrell, 1998: 44).

Combs \& Slaby (in Gimpel \& Merrell, 1998: 45) argues that social skills are the ability to interact with others in social contexts in specific ways that are socially acceptable as well as values and at the same time useful for themselves and people other. Social skills are complex abilities possessed by a person, where the person is able to distinguish positive or negative behavior, and will not perform behavior that will be punished or disliked by the environment (Libet and Lewinson, in Gimpel \& Merrell, 1998: 47).

According to Matson (in Gimpel \& Merrell, 1998: 49) social skills both directly and indirectly help adolescents to be able to adjust to the standards of community expectations in the norms that apply around them. So there are five dimensions of social 
Elda Ayumi, Iskandar Zulkarnain, Yan Hendra / JURNAL TARBIYAH 26 (2) (2019) 315-332

skills that should be possessed by adolescents, namely the dimensions of peers, selfmanagement, academic ability, compliance, and assertive behavior. There are six benefits of social skills, namely personality and identity development, developing work skills, productivity, and career success, improving quality of life, improving physical health, improving psychological health, and coping with stress.

There are seven factors that influence the development of social skills, namely family, environment, personality, recreation, association with the opposite sex, friendship education and group solidarity, employment. The ability of adolescent social skills is also determined by factors that determine the personality itself both internal and external. Internal factors include healthy physical conditions, good learning processes, pleasant experiences, and being able to overcome conflicts in order to create good social skills with the surrounding environment. While external factors, namely family parenting, harmonious relationships within the family so as to create an atmosphere full of love, warmth, cheerfulness, as well as the role of the community, the role of schools, culture and religion are also indications of good social skills if all goes in harmony (Sunarto and Hartono, 2002: 76).

\section{Teenagers}

The term teenager comes from the Latin word adolescence which means "to grow" or "body to mature". The term adolescence includes mental, emotional, social and physical maturity (Hurlock, 1980: 189). The beginning of adolescence lasts approximately from the age of thirteen to sixteen or seventeen years and the end of adolescence begins from the age of sixteen or seventeen years to eighteen years.

Piaget (Hurlock, 1980: 264) said that psychologically adolescence is the age where individuals integrate with adult society, the age of children no longer feels below the level of older people but is at the same level, at least in matters of rights. Integration in society (adults) has many effective aspects, more or less related to puberty. Also includes striking intellectual change. This intellectual transformation that is typical of adolescent thinking makes it possible to achieve integration in adult social relationships, which is in fact a common characteristic of the developmental period.

Harold Alberty (Makmun, 2004: 53) states that the period of adolescence can be defined generally as a period of developmental greetings experienced by an individual that stretches from the end of childhood until the coming of the beginning of adulthood 
Mappiare (in M. Ali and M. Asrori, 2009: 38), adolescence lasts between the ages of 12 years to 21 years for women and 13 years to 22 years for men. Whereas Hurlock divides the age range of teenagers into two parts, namely the ages 12/13 years to $17 / 18$ years are early adolescents, ages 17/18 years to $21 / 22$ years are late teens.

\section{RESEARCH METHOD}

This study uses a quantitative approach. A quantitative approach according to Arikunto (2006: 12) is a study that uses a lot of numbers, starting from data collection, interpretation of data and the appearance of the results. According to Azwar (2008: 61) research with a quantitative approach emphasizes his analysis of numerical data (numbers) processed by statistical methods. Basically, a quantitative approach is carried out in inferential research (in the context of testing hypotheses). With quantitative methods will be obtained the significance of group differences or the significance of the relationship between the variables studied.

This type of research is quantitative correlational which aims to determine the relationship between independent variables with the dependent variable. Correlational research is research that is intended to determine whether there is a relationship between two or several variables. With correlation techniques, researchers can find out the relationship of variation in a variable with other variations, the magnitude or height of the relationship is expressed in the form of a correlation coefficient. This study uses a correlational method because it aims to look at the Relationship of Online Game Addiction With Youth Social Skills among Communication Sciences Students of North Sumatra State Islamic University, Medan.

\section{RESULTS AND DISCUSSION}

Based on observations made at the North Sumatra State Islamic University in Medan, researchers see that the majority of students who play online games spend some of their free time playing online games with their friends. From these observations it can also be seen that students who play online games tend to rarely socialize with the surrounding environment because their time is spent playing online games and it is not uncommon for students who are addicted to online games to spend their money on buying equipment to play online games. Online games make these students do not have time to socialize and develop the social skills they have. 
Elda Ayumi, Iskandar Zulkarnain, Yan Hendra / JURNAL TARBIYAH 26 (2) (2019) 315-332

\section{Results}

Based on the results of the questionnaire data analysis, the subjects can be classified into three categories: high, medium and low. Meanwhile, to determine the distance of each level of classification in advance the average score (mean) and standard deviation of each variable are sought. From the results of calculations with the SPSS 25.0 application, to find a description of the level of online game addiction. Based on the results of testing through the application SPSS 25.0, the results show that the mean value of the online game addiction variable is 87.48 with a standard deviation of 7.173. It can be seen that the level of addiction to online games for adolescent students of Communication Science at the North Sumatra State Islamic University in Medan is in the medium category, with 129 subjects (69.4\%) while for the high category 25 subjects (13.4\%), and in the low as many as 32 subjects (17.2\%). Based on the results of the questionnaire data analysis, the subjects can be classified into three categories, namely: high, medium and low, whereas to determine the distance of each classification level, the average score (mean) and standard deviation of each are first sought. - each variable. From manual calculations using formulas to find out the description of the level of social skills, the calculation is based on a hypothetical score.

Based on the results of testing through the application of SPSS 25.0, the results show that the mean value of the teenage social skills variable is 56.82 with a standard deviation value of 6.425. It can be seen that the level of social skills of adolescent students of Communication Studies at the North Sumatra State Islamic University in Medan is in the medium category, namely as many as 159 people (85.5\%) and then as many as 11 people (5.9\%) are in the high category, whereas for low category of 16 people (8.6\%).

From the results of calculations using the SPSS 25.0 application above, it is found that the relationship between the variables of online game addiction and teenage social skills is 0.215 with a significance value $=0.003$. This shows that there is a positive relationship between the two variables. Based on the test results it can be concluded that there is a positive and significant relationship between online game addiction and social skills. From the above calculations it can be seen that the hypothesis proposed by the researcher is accepted. This positive relationship shows that the higher the addiction to online games, the social skills of North Sumatra State University Communication Studies Students will decrease.

Based on observations made at the North Sumatra State Islamic University in Medan, researchers see that the majority of students who play online games spend some 
Elda Ayumi, Iskandar Zulkarnain, Yan Hendra / JURNAL TARBIYAH 26 (2) (2019) 315-332

of their free time playing online games with their friends. From these observations it can also be seen that students who play online games tend to rarely socialize with the surrounding environment because their time is spent playing online games and it is not uncommon for students who are addicted to online games to spend their money on buying equipment to play online games. Online games make these students do not have time to socialize and develop the social skills they have.

\section{Discussion}

\section{Level of Social Skills}

From the results of the study it can be seen that the social skills abilities of adolescents in the Communication Sciences Students of North Sumatra State Islamic University Medan are in the middle category, namely as many as 159 people (85.5\%). This identifies that adolescents who have low levels of social skills these are those who have a pattern of social skills in a normal level meaning, the ability of skills and act in the environment are still influenced by physical, psychological, and environmental skills.

Then the distribution results in the low category of 16 people (8.6\%), this identifies that adolescents who are still unable to show themselves in the social environment optimally and have not been able to adapt to the surrounding social environment. Whereas adolescents who have a high level of social skills are 11 people (5.9\%) which indicates that they are adolescents whose social behavior is in accordance with the group's standard values and can meet the expectations of the group, able to adjust well to various groups, can show a pleasant attitude towards others, towards social participation and towards his role in social groups as well as being satisfied with his social contacts and to the role played in social situations.

Interacting and dealing with fellow humans is a very important need for human life. In addition to nature humans are social creatures, who need a relationship with each other to be able to live and develop normally. Teenagers as social creatures that live in groups are expected to be able to interact with others so that they can be said to be teenagers who can adjust well according to the stage of development of their age. Therefore, adolescents are required to have the ability of social skills, both within the family, school / campus, and within the community where he lives.

Meanwhile, according to Wilis (2005: 64), good social information is a person's ability to live and get along naturally with the environment, so adolescents feel satisfied with themselves and the environment. Good social skills will be one important provision 
Elda Ayumi, Iskandar Zulkarnain, Yan Hendra / JURNAL TARBIYAH 26 (2) (2019) 315-332

because it will help teens when they are involved in the wider community. In Islam it is highly recommended to carry out social interactions. Teenagers who perform social skills means that he has established a relationship of friendship and friendship with those around him. Allah SWT mentions the person who succeeded in establishing brotherhood as Ulul Al-baab (a rational person).

Teenagers who can show a pleasant attitude towards others, towards social participation as well as to their role in the group, the teenager will adjust well socially. Social skills in an Islamic perspective are interpreted as silaturrahim relations. Every human being who has faith is obliged for them to maintain silaturrahim because Allah Almighty hates those who break silaturrahim. Silaturrahim has benefits and a very positive influence on one's mental condition, such as friendship with others can eliminate boredom, fatigue, loneliness and can reduce the tension of one's soul and emotions. More deeply, friendship will also make a person have many relationships, many friends and acquaintances, find close and trusted friends, so someone will exchange ideas with him about various things that happen to him.

\section{Online Games Addiction}

From the results of the study showed that the average teen gamers in the Communication Sciences Students of North Sumatra State Islamic University Medan were in the medium category. The distribution of teenage online game addiction among the Communication Sciences Students of North Sumatra State Islamic University Medan for the medium category is 129 subjects (69.4\%). Where this indicates that the teenage gamers in the Communication Sciences Students of North Sumatra State Islamic University Medan are able to resist the urge to continuously play online games. It also indicates that teenage gamers in the Communication Science Students of North Sumatra State Islamic University of Medancere are able to withdraw from the world of online gaming and they are capable enough to manage the use of time to play online games, in addition they are also quite capable to regulate how their relationship with others and also their attention about personal health issues. While 32 subjects (17.2\%) were at a low level, this shows a good level at the level of online gaming addiction for teen gamers in Communication Sciences Students of North Sumatra State Islamic University Medan.

Low category in online game addiction indicates that there is a good ability to withdraw from the world of online gaming, able to resist the urge to play online games, 
able to manage the use of time to play online games and be able to manage good relationships with others and pay attention to health problems.

From the data collected, it can be seen that young gamers who are used as research subjects that are high as many as 25 subjects (13.4\%) of them included in the high category, this indicates that there is an inability to withdraw from the world of online gaming, inability to resist the urge to play online games, the inability to manage the use of time to play online games and the inability to manage good relationships with other people and pay less attention to health problems. From these results indicate that the level of teenage online game addiction among Communication Sciences Students of North Sumatra State Islamic University Medan varies. The level of online game addiction varies due to several aspects that make a person addicted to online games. The aspect of someone addicted to online gaming is actually almost the same as other types of addiction, but online gaming addiction is included in the category of psychological addiction and not physically addicted.

Addicted to online games can make people forget everything and even forget to Allah SWT. If someone is addicted to online games then he will not pay attention to the things that happen around him, not infrequently they also neglect their obligations as a Muslim just to linger playing online games. Many teens who are addicted to online games number one game rather than worship, so the addictions of online games are far from Allah's side. God in his word also explains that being by God is better than playing games. And they only harm themselves.

\section{Relationship of Online game addiction with Social Skills in Teenagers}

The results of the analysis using Karl Pearson Product Moment correlation analysis, it is known that there is a proven positive relationship between the level of online game addiction and social skills. This can be seen from the correlation coefficient of 0.15 and is positive with a probability (sig) of 0.003 . Based on the Sig. (2-tailed) of 0.003 which is smaller than the significant level $(\alpha) 5 \%$ shows that there is a significant relationship between social skills variables $(\mathrm{Y})$ and online game addiction $(\mathrm{X})$ and the relationship between the two is a positive relationship meaning that if addicted to online games has increased, then the tendency of adolescent social skills will decrease in adolescent gamers in the Communication Sciences Students of North Sumatra State Islamic University Medan. 
Someone who is able to adjust to his social well is not only influenced by one factor, but because it is influenced by various factors. The process of social skills is determined by the factors that determine the personality itself well. As for the results of the Davis and Forstythe study (Mu'dadin, 2002: 64) also explains the factors that influence social skills, including family which is the first and foremost place for children to get an education. Psychic satisfaction obtained by children in the family will determine how adolescents will react to the environment. Children raised in families that are not harmonious or broken home where children do not get enough psychological satisfaction to eat children will find it difficult to develop social skills.

Another factor is the environment within this boundary covers the physical environment (home, house) and social environment (neighbors), the environment also includes the family environment (primary and secondary family), the school environment and the wider community. With the introduction of the environment from an early age the child will already know that he has a broad social environment, not only consisting of siblings, parents, or grandparents only. Besides personality factors, in general appearance is often identified from a person's personality, but actually not. Because what appears does not always describe the real person. Parents in this case play a role to provide values to respect the dignity and dignity of others without basing on physical things such as material or appearance. Interrelation with the opposite sex also determines a person's social skills to get roles according to gender, so children and adolescents should not be restricted to associations only with friends who have the same sex. Education, basically schools teach various skills to children. One of these skills is social skills which are said to be efficient learning methods and various learning techniques according to the type of learning.

Someone who is addicted to online games will sacrifice time and money just to linger in front of a computer or smartphone playing online games. They no longer care about what is happening in their surroundings, where a sense of ignorance about the environment or one's own condition is an indicator of poor social skills. As explained by Lawton (in Hurlock, 1997: 78), someone who has good social skills includes individuals who are able to meet their environmental expectations, are willing to accept responsibility and dare to take risks for their actions, regardless of what happens in the surrounding environment, can work together with people, respect each other and respect others, be disciplined in the tasks and problems that occur in a group environment, immediately handle problems that require resolution, know how to work when it's time to work and 
play when it's time to play, make decisions happily, without conflict, and without asking for much advice and can compromise when faced with difficulties.

Social skills are one of the important factors in the general social development of individuals for children, adolescents, and adults. In accordance with the Durkin explanation (in Hartati, 2005: 42) social skills are very important for someone to support future success in establishing relationships with people around him. Briefly said that the ability of good social skills will be able to use their knowledge and skills in relationships and can advance the positive aspects of the relationship. Teenagers who have bad social relationships will find it difficult to plunge into the outside world. Therefore, a teenager who has poor social skills when in a particular community he will tend to join in with that community without thinking and does not have a strong stance in him.

It is common to find many teenagers during their lecture hours playing games in the campus, canteen or in cafes, even some of them wear campus uniforms (almamater) when they play online games in cafes. It is also uncommon to find adolescents who not coming home and not sleeping at night only to play online games. In Islam, it is highly recommended to carry out social interactions. Teenagers who do social means he has established a relationship of friendship around him. Allah SWT mentions that the person who succeeded in establishing brotherhood as Ulul Al-baab (a rational person). Allah SWT created humans with various differences in order to know each other.

Teenagers who can show a pleasant attitude towards social participation as well as to their role in the group, the teenager will adjust well socially. Social skills in an Islamic perspective are interpreted as silaturrahim relations. Every human being who has faith is obliged for them to maintain silaturrahim because Allah Almighty hates those who break silaturrahim. The theory that I use in this research is the sociopsychological theory of communication, in this study most of the students have a strong influence on any media, including online games, resulting in very low social skills among students.

\section{CONCLUSION}

Based on the calculation of the product moment correlation coefficient obtained. This shows that there is a positive relationship between two variables. Based on the test results it can be concluded that there is a positive and significant relationship between online game addiction and social skills. From the above calculations, it also can be seen that the hypothesis proposed by the researcher is accepted. The positive relationship 
Elda Ayumi, Iskandar Zulkarnain, Yan Hendra / JURNAL TARBIYAH 26 (2) (2019) 315-332

shows that the higher the online game addiction, the social skills of the North Sumatra State University of Medan Communication Sciences Students will decrease.

1. Addiction Online game level in Communication Science Students of North Sumatra State Islamic University Medan. It shows that the majority of online gaming addictions are in the moderate category.

2. Youth Social Skills level in Communication Sciences Students of North Sumatra State Islamic University, Medan. It shows that the majority of social skills are in the moderate category. From the results of hypothesis testing it can be seen that the Sociopsychological Theory by the connection of this study can be accepted.

\section{REFERENCES}

Agung Sunarto dan Agung Hartono. 2006. Perkembangan Peserta Didik, Jakarta: PT. Asdi Mahasatya.

Ali, M dan Asrori, M. (2009). Psikologi Remaja Perkembangan Pesera Didik. Jakarta : Bumi Aksara.

Arikunto, S. 2006. Manajemen Penelitian. Jakarta: Rineka Cipta.

Azwar, S. 2008. Sikap manusia: Teori dan pengukurannya (ed.4). Yogyakarta: Pustaka Pelajar.

Cartledge, C., \& Milburn, J. F. 1995. Teaching Social Skill to Children and Youth: Innovative Approaches (3rd ed). Needham Heights, MA: Allyn \& Bacon.

Deswita. 2006. Psikologi Perkembangan. Bandung: Remaja Rosdakarya.

Dodge, K. A., Pettit, G. S., Gregory, S., McClaskey, C. L., \& Brown, M. M. 1986. Social Competence in Children. Monographs of the Society for Research in Child Development, $51,1-85$.

Effendy, Onong Uchjana. 2013. Ilmu Komunikasi Teori dan Praktek. Bandung: Remaja Rosdakarya.

Gimpel, G. A., \& Merrell, K. W. 1998. Social Skills of Children and Adolescent: Conceptualization, Assessment, Treatment. New Jersey: Lawrence Erlbaurn Associates Publisher.

Hartati Sofia. (2005). Perkembangan Belajar Pada Anak Usia Dini. Jakarta: Departemen Pendidikan Nasional

Hurlock, B. Elizabeth. 1997. Psikologi Perkembangan Suatu Pendekatan Sepanjang Rentang Kehidupan (Edisi Kelima). Terjemahan oleh Istidawanti \& Soedjarwo. Jakarta: Erlangga. 
Elda Ayumi, Iskandar Zulkarnain, Yan Hendra / JURNAL TARBIYAH 26 (2) (2019) 315-332

Kim. Hyo-Jun. 2002. Improving The Vehicle Performance with Active Suspension Using Road-Sensing Algorithm. Elcevier Science Ltd.

Littlejohn, Stephen W. and Karen A. Foss. 2009. Encylopedia of CommunicationTheory. Los Angeles: Sage.

Makmun, A.S. 2004. Psikologi Kependidikan. Bandung: PT. Remaja Rosdakarya.

Mc.Quail. 2011. Mass Communication Theory. London: Sage Publications.

Merrel, K. W \& Gimpel, G. A. 1998. Social Skill of Children and Adolescents Conceptualization, Assessment, Treatment. New Jersey London. Lawrence Erlbaum Associates.

Mulyana, Deddy. 2010. Ilmu Komunikasi Suatu Pengantar. Bandung: Remaja Rosdakarya.

Nurjaman, Kadar dan Khaerul Umam. 2012. Komunikasi \& Public Relations. Bandung: CV Pustaka Setia.

Orleans, M. \& Laney, M. C. 1997. Early Adolescent Computer Use: Isolation or Sociation, Sociology Department, CSUF.

Santrock (2003) John W. Adolescence, Perkembangan Remaja. Edisi Keenam. Jakarta: Erlangga

Sofyan S. Wilis. 2005. Remaja dan Masalahnya (Mengupas Berbagai Bentuk Kenakalan Remaja Seperti Narkoba, Free Sex dan Pemecahannya). Bandung: Alfabeta.

Winn, B. M dan Fisher, J. W. 2004. Design of Communication, Competition, and Collaboration in Online Games. Dipresentasikan dalam computer game technology conference. Toronto, Canada. (3 Februari 2019).

Young, K. 2000. Cyber-Disorders: The Mental Health Concern for the New Millenium. $\begin{array}{lllll}\text { Cyber Psychology } \quad \& \quad \text { Behavior, } & \text { 3(5), }\end{array}$ 479.www.netaddiction.com/net.compulsions.htm(01-02-2019)

Yusuf, S. 2000. Psikologi Perkembangan Anak dan Remaja. Bandung: PT. Remaja Rosdakarya. 